\title{
THE INCIDENCE OF CANCER FOLLOWING TOTAL HIP REPLACEMENT
}

\author{
W. J. GILlESPIE, C. M. A. FRAMPTON, R. J. HENDERSON, P. M. RYAN
}

From Christchurch Hospital, New Zealand

\begin{abstract}
We have studied the incidence of tumours at remote sites following total hip replacement: 1358 individuals have been followed up for 14,286 person-years after operation. In the decade following implantation the incidence of tumours of the lymphatic and haemopoietic systems was significantly greater, and that of cancer of the breast, colon, and rectum, significantly less than expected. Whilst the association might be due in part to an effect of the prosthetic implants, other mechanisms, particularly drug therapy, require consideration.
\end{abstract}

It is biologically plausible that implantation in human tissues of the components of joint replacement might provoke reaction leading to the development of malignant tumours, either at the site of implantation or elsewhere. Metallic corrosion products can be found not only in tissue adjacent to the implant (Coleman, Herrington and Scales 1973; Lux and Zeisler 1974) but in the circulation, the urine and in remote tissue sites (Dobbs and Minski 1980; Woodman et al. 1982). Wear debris from implants may accumulate locally or at a distance in the lymphatic system (Walker and Bullough 1973).

Many of the constituents of joint implants are indeed carcinogenic in experimental models. Methyl methacrylate is a bacterial mutagen (Poss, Thilly and Kaden 1979), although the liquid monomer fails to produce skin cancer upon topical application in rats (Oppenheimer et al. 1955). Polymethyl methacrylate film (Laskin, Robinson and Weinman 1954) and particulate polyethylene (Carter and Roe 1969; Memoli et al. 1986) can induce local sarcomas and other tumours in rats. Sunderman (1984) has reviewed evidence from in vitro studies, including bacterial and mammalian cell mutagenesis, chromosomal damage, mammalian cell transformation, and disturbances of DNA replication. In all of these, cobalt, chromium and nickel have demonstrated adverse effects. These metals are also carcinogenic in a

W. J. Gillespie, ChM, FRCS Ed, FRACS, Professor of Orthopaedic Surgery

C. M. A. Frampton, BSc, Biostatistician

R. J. Henderson, BSc, Medical student

P. M. Ryan, BSc, Medical student

Christchurch School of Medicine, University of Otago, P.O. Box 4345, Christchurch, New Zealand.

Correspondence should be sent to Professor W. J. Gillespie.

(C) 1988 British Editorial Society of Bone and Joint Surgery

$0301-620 X / 88 / 4186 \$ 2.00$

J Bone Joint Surg [Br] 1988;70-B:539-42. number of animal models (Heath 1960; Swanson, Freeman and Heath 1973; Memoli et al. 1986) as are iron-carbohydrate complexes (Sunderman 1978).

Despite the experimental evidence and the observation that the inhalation of nickel and chromium is clearly associated with lung and sinusoidal carcinomas (Sunderman 1984), few local human tumours have been described after joint replacement. Citing a number of case reports, Hamblen and Carter (1984) concluded that "the number of reported cases of sarcoma is so minute, compared with the vast number of replaced hips, that no surgeon or patient should feel undue concern on this account; especially as the short latent period of the three cases described suggests that the malignancy could be coincidental". However, the latency of the increased risk of lymphoma and other tumours after renal transplantation is relatively short (Kinlen et al. 1979). Ageing, furthermore, may enhance both initiation and promotion of tumour growth (Anisimov 1983). Black (1984) drew attention to the absence of data on the association of total hip replacement and cancer incidence, and expressed concern about both implant site and remote tumours.

Our study examines the hypothesis that the incidence of tumours at remote sites in individuals who have had a total hip replacement might differ from that in the general population.

\section{METHOD}

From the morbidity records of five New Zealand Public Hospitals and from the records of one private surgical practice 1358 individuals were identified who had had a total hip replacement in the period 1966 to 1973 . The New Zealand Cancer Registry was searched from 1966 to 1983 inclusive to identify which of these 1358 individuals had developed malignant tumours. The Register of Deaths was searched over the same period. Confirmation of survival was sought by scrutiny of 
electoral rolls. Cancer rates by age and sex were extracted from data published annually by the New Zealand Health Statistics Centre.

Each individual was accorded a unique number and tabulations were prepared listing this number, date of birth, date of operation, date of registration of cancer, diagnostic code (International Classification of Disease, ICD) and date of death. The data were committed to disk and analysed on a VAX computer. A Fortran programme was written to calculate expected cancer incidences, given the national age and sex specific cancer rates for each calendar year studied.

The technique of Miettinen (1974) was used to test the hypothesis of an increase or decrease in incidence. (The standard technique, in which the observed number of cancers is assumed to be distributed as a random Poisson variable around the expected number, and the probabilities are calculated as "exact" values, has been shown to give a conservative estimate of the actual difference.) Both Miettinen-corrected p-values and exact Poisson values were calculated. When the two differed within the standard ranges for $\mathrm{p}$-values, the more conservative values were taken.

For 298 individuals, confirmation of death or survival was not available. They were assumed to be healthy survivors for the purposes of the main analysis. Some may have died under other names or left the country. As the expected figures for cancer incidence in the study population might therefore be potentially overestimated, the data was reanalysed with these individuals removed.

\section{RESULTS}

The mean follow up period of 1358 individuals was 10.52 years (range six months to 17 years), giving a follow-up of 14,286 person-years for the population studied. In all, 164 cancers were recorded.

The number of person-years available for analysis at each chosen interval of follow-up is shown in Table I. A significant decrease was seen in general cancer incidence up to 10 years after operation (Table II). By contrast, a significant increase was seen in those followed for longer than 10 years. Cancer of the breast (ICD 174) and cancer of the colon and rectum (ICD 153 and 154) showed significant decrease in incidence up to 10 years after hip replacement $(p<0.01)$. The incidence of cancer of the bronchus and lung (ICD 162) was within expected limits throughout the study (Tables III to V).

There was a significant increase overall in the incidence of tumours of the lymphatic and haemopoietic systems (ICD 200 to 208). The cumulative effect remained significant through the entire study period (Table VI). If tumours registered in the first two years after total hip replacement were excluded the increase in incidence in the remainder of the study period remained but lost significance (observed 16, expected 10.57,
Table I. Person-years available for analysis

\begin{tabular}{ll}
\hline $\begin{array}{l}\text { Follow-up } \\
\text { in years }\end{array}$ & Person-years \\
\hline Less than 1 & 1328 \\
1 to $<2$ & 1293 \\
2 to $<5$ & 3687 \\
5 to $<10$ & 5330 \\
Over 10 & 2648 \\
Total & 14,286 \\
\hline
\end{tabular}

Table II. Results for all cancers

\begin{tabular}{|c|c|c|c|c|}
\hline \multirow[b]{2}{*}{$\begin{array}{l}\text { Follow-up } \\
\text { in years }\end{array}$} & \multicolumn{2}{|l|}{ Cancers } & \multirow[b]{2}{*}{$\begin{array}{l}\text { Standardised } \\
\text { morbidity ratio }\end{array}$} & \multirow[b]{2}{*}{$\begin{array}{l}95 \% \text { confidence } \\
\text { intervals }\end{array}$} \\
\hline & Observed & Expected & & \\
\hline Less than 1 & 17 & 12.99 & 1.31 & \\
\hline 1 to $<2$ & 6 & 13.02 & $0.46^{*}$ & 0.18 to 1.04 \\
\hline 2 to $<5$ & 26 & 42.45 & $0.61^{* *}$ & 0.41 to 0.91 \\
\hline 5 to $<10$ & 58 & 75.36 & $0.77^{\star}$ & 0.58 to 1.00 \\
\hline Over 10 & 57 & 35.58 & $1.60^{* *}$ & 1.22 to 2.09 \\
\hline Total & 164 & 179.40 & 0.91 & \\
\hline 0 to $<10$ & 107 & 143.8 & $0.74^{* *}$ & 0.61 to 0.90 \\
\hline
\end{tabular}

* $p<0.05 * * \mathrm{p}<0.01$

Table III. Results for cancer of the breast (ICD 174)

\begin{tabular}{|c|c|c|c|c|}
\hline \multirow{2}{*}{$\begin{array}{l}\text { Follow-up } \\
\text { in years }\end{array}$} & \multicolumn{2}{|l|}{ Cancers } & \multirow{2}{*}{$\begin{array}{l}\text { Standardised } \\
\text { morbidity ratio }\end{array}$} & \multirow{2}{*}{$\begin{array}{l}95 \% \text { confidence } \\
\text { intervals }\end{array}$} \\
\hline & Observed & Expected & & \\
\hline Less than 1 & 0 & 1.31 & & \\
\hline 1 to $<2$ & 0 & 1.35 & & \\
\hline 2 to $<5$ & 1 & 4.24 & 0.24 & \\
\hline 5 to $<10$ & 2 & 6.68 & $0.30^{*}$ & 0.04 to 1.17 \\
\hline Over 10 & 3 & 2.97 & 1.01 & \\
\hline Total & 6 & 16.55 & $0.36^{* *}$ & 0.14 to 0.82 \\
\hline 0 to $<10$ & 3 & 13.58 & $0.22^{* *}$ & 0.05 to 0.69 \\
\hline
\end{tabular}

$* \mathrm{p}<0.05 * \mathrm{p}<0.01$

$\mathrm{p}=0.07$ ). The diagnosis at operation of the 21 individuals recorded as having suffered tumours of the lymphatic and haemopoietic system was identified as osteoarthritis in 17 cases, rheumatoid arthritis in two, Paget's disease in one and idiopathic aseptic necrosis in one.

When the 298 individuals of uncertain status at the end of follow-up were removed completely from the study, the decrease in general cancer incidence was no longer significant. The overall decrease in incidence of 
Table IV. Results for cancer of colon and rectum (ICD 153, 154)

\begin{tabular}{lllll}
\hline & \multicolumn{2}{c}{ Cancers } & & \\
\cline { 2 - 4 } $\begin{array}{l}\text { Follow-up } \\
\text { in years }\end{array}$ & Observed & Expected & $\begin{array}{l}\text { Standardised } \\
\text { morbidity ratio }\end{array}$ & $\begin{array}{l}95 \% \text { confidence } \\
\text { intervals }\end{array}$ \\
\hline Less than 1 & 1 & 3.26 & 0.31 & \\
1 to $<2$ & 0 & 2.44 & - & \\
2 to $<5$ & 3 & 7.92 & $0.38^{*}$ & 0.09 to 1.18 \\
5 to $<10$ & 7 & 13.43 & $0.52^{*}$ & 0.22 to 1.11 \\
Over 10 & 10 & 6.75 & 1.48 & \\
Total & 21 & 33.81 & $0.62^{*}$ & 0.39 to 0.96 \\
0 to $<10$ & 11 & 27.06 & $0.41^{* *}$ & 0.21 to 0.74 \\
\hline * $\mathrm{p}<0.05$ & $* * \mathrm{p}<0.01$ & & &
\end{tabular}

Table V. Results for cancer of bronchus and lung (ICD 162)

\begin{tabular}{llll}
\hline & \multicolumn{2}{l}{ Cancers } & \\
\cline { 2 - 3 } $\begin{array}{l}\text { Follow-up } \\
\text { in years }\end{array}$ & Observed & Expected & $\begin{array}{l}\text { Standardised } \\
\text { morbidity ratio }\end{array}$ \\
\hline Less than 1 & 2 & 2.83 & 0.71 \\
1 to $<2$ & 2 & 2.14 & 0.93 \\
2 to $<5$ & 8 & 6.87 & 1.16 \\
5 to $<10$ & 6 & 11.20 & 0.54 \\
Over 10 & 8 & 5.31 & 1.51 \\
Total & 26 & 28.36 & 0.92 \\
\hline
\end{tabular}

Table VI. Results for tumours of the lymphatic and haemopoietic systems (ICD 200 to 208)

\begin{tabular}{lllll}
\hline & \multicolumn{2}{l}{ Cancers } & & \\
\cline { 2 - 4 } $\begin{array}{l}\text { Follow-up } \\
\text { in years }\end{array}$ & Observed & Expected & $\begin{array}{l}\text { Standardised } \\
\text { morbidity ratio }\end{array}$ & $\begin{array}{l}95 \% \text { confidence } \\
\text { intervals }\end{array}$ \\
\hline Less than 1 & 5 & 0.96 & $5.26^{* *}$ & 1.85 to 12.70 \\
1 to $<2$ & 0 & 0.96 & & \\
2 to $<5$ & 5 & 3.09 & & \\
5 to $<10$ & 7 & 5.07 & & \\
Over 10 & 4 & 2.41 & & 1.06 to 2.60 \\
\hline Total & 21 & 12.49 & $1.68^{*}$ & \\
\hline$* 00.05$ & $* *$ & &
\end{tabular}

${ }^{*} \mathrm{p}<0.05 * * \mathrm{p}<0.01$

cancer of the breast remained (observed $=5$, expected $=11.59, \mathrm{SMR}=0.43, \mathrm{p}<0.05)$ as did the decrease up to 10 years from implantation (observed $=2$, expected $=9.80, \mathrm{p}<0.001)$. The decrease over the same period for cancer of the colon and rectum remained significant (observed $=10$, expected $=19.92, \mathrm{p}<0.01$ ). The overall increase in incidence of tumours of the lymphatic and haemopoietic systems remained significant (observed $=20$, expected $=8.89, \mathrm{p}<0.01$ ). With tumours registered within two years of surgery excluded, the increase in incidence of tumours of the lymphatic and haemopoietic system remained significant (observed $=$ 15 , expected $=7.39, \mathrm{p}<0.05$ ).

\section{DISCUSSION}

Our study has demonstrated an apparent association between total hip replacement and the incidence of remote malignant tumours in the decade following implantation. A number of possible explanations require consideration.

1. The apparent association may be a mathematical curiosity. Given the statistical parameters chosen, that probability is less than $5 \%$.

2. The quality of the data may be open to question. The accuracy of the data stored in the New Zealand Cancer Registry is however considered to have been good during the period studied, with the possible exception of the figures for melanoma (Clark AM, personal communication, 1987) which may have been under-registered by around $10 \%$. Uncertainty over the status of 298 individuals at the time of completion of the study could have resulted in an underestimate of observed incidence of cancer. The apparent reduction in the incidence of cancers in general requires to be interpreted with caution, since it is no longer apparent when these individuals are removed from the study. Further epidemiological studies are certainly required.

3 . The relative risk of cancer in the study population might have been influenced by the underlying hip disease or by associated intrinsic factors. It has been suggested that there is an increased incidence of lymphoma and of leukaemia associated with rheumatoid arthritis (Prior et al. 1984) or with its treatment (Kinlen 1985). These associations are controversial (Castor and Bull 1985). In any event the great majority of hip replacements are carried out for osteoarthritis, whose aetiology remains for the most part obscure; it may represent the end stage of a number of different processes, any one of which might have an effect on susceptibility to cancer.

4. The relative risk might be affected by the medical treatment of the underlying disease. Hip replacement is widely employed for cases of aseptic necrosis of the hip after renal transplantation. However, none of those in whom lymphoma developed had undergone transplantation. The possible effect of immunosuppressive therapy in rheumatoid arthritis has already been mentioned. An association has been proposed between phenylbutazone, a drug readily available in New Zealand in the early part of the study period, and the development of leukaemia and non-Hodgkins lymphoma (Bean 1960; Jensen and Rou 1965; Cartwright et al. 1987). Prostaglandins may be associated with tumour growth and invasiveness, and may inhibit the immune response of the host. The administration of the prostaglandin synthetase inhibitor indomethacin, widely used in osteoarthritis, has been 
shown to inhibit the growth of transplanted tumours in rats (Blitzer and Huang 1983) and prostaglandinproducing suppressor cells have been identified in lymphoma (Goodwin et al. 1977). The excess of tumours of the lymphatic and haemopoietic system registered within the first year after joint replacement is in favour of an effect which precedes operation. Drug therapy over a period of years could produce such an effect.

5. Social and occupational factors associated with the development of lymphatic neoplasms in New Zealand include some types of agriculture-related employment and exposure to certain pesticides (Pearce, Smith and Fisher 1985; Pearce et al. 1986). The representation of these groups in this study is not known. The incidence of leukaemias appears to be higher in Maori than European New Zealanders (Beard et al. 1985).

6. The relative risk might be altered by one or more of the constituents of joint replacement. The theoretical basis for this possibility has been discussed in the introduction. Such an effect is not excluded by the data we have presented.

Our results are compatible with a hypothesis of chronic stimulation of the immune system, encouraging the emergence of lymphoreticular malignancies but, by increasing immune surveillance, inhibiting the overt development of some epithelial cancers. Specific experimental studies to examine possible mechanisms may now be justified.

From the viewpoint of both the surgeon and the prospective recipient of joint replacement, the evidence brought forward from this study should not detract from the potential benefit of joint replacement. The risk of developing a lymphoreticular neoplasm remains small, increasing from 2 per 1000 over 10 years in the population as a whole to 6 per 1000 in the same period in the operated group. There may be a protective effect in the first decade for other more common tumours. Nevertheless, the long term biological effects of implants, as well as of drugs, require more detailed attention as their use increases and as new materials are introduced.

The authors are grateful to the orthopaedic surgeons of Dunedin, Greymouth, Christchurch, Lower Hutt and Auckland, who gave access to their records for the study; to the Cancer Society of New Zealand for providing a grant for RJH and to the Chief Health Statistician of the New Zealand Health Statistics Centre, Mr I. Fraser, and Professor D.

C. G. Skegg for help and advice.

No benefits in any form have been received or will be received from a commercial party related directly or indirectly to the subject of this article.

\section{REFERENCES}

Anisimov VN. Carcinogenesis and aging. Adv Cancer Res $1983 ; 40: 365-424$.

Bean RH. Phenylbutazone and leukaemia: a possible association. $\mathrm{Br}$ Med J 1960:2:1552-5.

Beard ME, Hart DN, Hawkins P, Southern M, Fitzgerald PH. Leukaemia/lymphoma incidence in New Zealand: acute leukaemia subtypes in the South Island of New Zealand 1983-1984. Leuk Res 1985;9:803-7.
Black J. Systemic effects of biomaterials. Biomaterials 1984;5:11-8.

Blitzer A, Huang CC. The effect of indomethacin on the growth of epidermoid carcinoma of the palate in rats. Arch Otolaryngol 1983;109:719-23.

Carter RL, Roe FJC. Induction of sarcomas in rats by solid and fragmented polyethylene: experimental observations and clinical implications. Br J Cancer 1969;23:401-7.

Cartwright RA, Bernard SM, Bird CC, et al. Chronic lymphocytic leukaemia: case control epidemiological study in Yorkshire. Br J Cancer 1987;56:79-82.

Castor CW, Bull FE. Review of United States data on neoplasms in rheumatoid arthritis. Am J Med 1985;78 (IA):33-8.

Coleman RF, Herrington J, Scales JT. Concentration of wear products in hair, blood, and urine after total hip replacement. $\mathrm{Br}$ Med J 1973;1527-9.

Dobbs HS, Minskj MJ. Metal ion release after total hip replacement. Biomaterials 1980;1:1933-8.

Goodwin JS, Messner RP, Bankhurst AD, et al. Prostaglandinproducing suppressor cells in Hodgkin's disease. $N$ Engl J Med 1977;297:963-8.

Hamblen DL, Carter RL. Sarcoma and joint replacement (editorial). $J$ Bone Joint Surg [Br] 1984;66-B:625-27.

Heath JC. The histogenesis of malignant tumours induced by cobalt in the rat. Br J Cancer 1960;14:478-82.

Jensen MK, Rou K. Phenylbutazone and leukaemia. Acta Med Scand 1965;178:505-13.

Kinlen LJ, Sheil AGR, Peto J, Doll R. Collaborative United KingdomAustralasian study of cancer in patients treated with immunosuppressive drugs. $\mathrm{Br}$ Med J 1979;2:1461-6.

Kinlen LJ. Incidence of cancer in rheumatoid arthritis and other disorders after immunosuppressive treatment. Am J Med 1985;78 (suppl 1A):44-9.

Laskin DM, Robinson IB, Weinman JP. Experimental production of sarcomas by methyl methacrylate implants. Proc Soc Exp Biol Med 1954;87:329-32.

Lux F, Zeisler R. Investigations of the corrosive deposition of components of metal implants and of the behaviour of biological trace elements in metallosis tissue by means of instrumental multielement activation analysis. J Radioanal Chem 1974;19:289-97.

Memoli VA, Urban R, Alroy J, Galante JO. Malignant neoplasms associated with orthopaedic implant materials in rats. $J$ Orthop Res 1986;4:346-55.

Miettinen OS. Comment. J Am Stat Assn 1974;69:380-2.

Oppenheimer BS, Oppenheimer ET, Danishefsky I, et al. Further studies of polymers as carcinogenic agents in animals. Cancer Res 1955:15:333-40.

Pearce NE, Smith AH, Fisher DO. Malignant lymphoma and multiple myeloma linked with agricultural occupations in a New Zealand Cancer Registry-based study. Am J Epidemiol 1985;121:225-37.

Pearce NE, Smith AH, Howard JK, et al. Non-Hodgkin's lymphoma and exposure to phenoxyherbicides, chlorophenols, fencing work, and meat works employment: a case-control study. $\mathrm{Br} J$ Ind Med 1986;43:75-83.

Poss R, Thilly WG, Kaden DA. Methylmethacrylate is a mutagen for Salmonella Typhimurium. J Bone Joint Surg [Am] 1979;61-A:1203-7.

Prior P, Symmons DP, Hawkins CF, Scott DL, Brown R. Cancer morbidity in rheumatoid arthritis. Ann Rheum Dis 1984;43:128-31.

Sunderman FW Jr. Carcinogenic effect of metals. Fed Proc 1978;37:40-6.

Sunderman FW Jr. Recent advances in carcinogenesis. Ann Lab Clin Sci $1984 ; 14: 93-122$.

Swanson SAV, Freeman MAR, Heath JC. Laboratory tests on total joint replacement prostheses. J Bone Joint Surg [Br] 1973;55-B : 759-73.

Walker PS, Bullough PG. The effects of friction and wear in articular joints. Orthop Clin North Am 1973;4:275-93.

Woodman JR, Jacobs JJ, Galante JO, et al. Titanium release from fiber metal composites in baboons: a long term study. Trans Orthop Res Soc 1982;7:166. 